Wilfrid Laurier University

Scholars Commons @ Laurier

1998

\title{
Perceiving and Feeling Personal Discrimination: Motivation or Inhibition for Collective action?
}

\author{
Mindi D. Foster \\ Wilfrid Laurier University, mfoster@wlu.ca \\ Kimberley Matheson \\ Carleton University, kim.matheson@carleton.ca
}

Follow this and additional works at: https://scholars.wlu.ca/psyc_faculty

Part of the Psychiatry and Psychology Commons, and the Social Psychology Commons

\section{Recommended Citation}

Foster, Mindi D. and Matheson, Kimberley, "Perceiving and Feeling Personal Discrimination: Motivation or Inhibition for Collective action?" (1998). Psychology Faculty Publications. 52.

https://scholars.wlu.ca/psyc_faculty/52

This Article is brought to you for free and open access by the Psychology at Scholars Commons @ Laurier. It has been accepted for inclusion in Psychology Faculty Publications by an authorized administrator of Scholars Commons@Laurier. For more information, please contact scholarscommons@wlu.ca. 
Running Head: Personal discrimination and collective action

Perceiving and Feeling Personal Discrimination:

Motivation or Inhibition for Collective action?

Mindi D. Foster

University of North Dakota

Kimberly Matheson

Carleton University, Ottawa, Canada

Keywords: personal discrimination, collective action

Abstract

Relative deprivation and group consciousness theories differ in their predictions of how personal discrimination and personal discontent will be related to taking collective action. According to relative deprivation theory, assessments of personal status should be unrelated to taking collective action. In contrast, group consciousness theories suggest that while perceiving personal discrimination is necessary for collective action to occur, feelings of personal discontent may inhibit it. Female students completed questionnaires assessing their perceptions of, and affective responses to personal discrimination, as well as their participation in collective actions. A hierarchical regression analysis found that personal discrimination and discontent interacted such that among women who perceived personal discrimination, women took the most collective actions when they did not feel personally discontent with their status. Implications for the relationship between negative emotions and intergroup behavior were discussed.

Perceiving and Feeling Personal Discrimination:

Motivation or Inhibition for Collective action?

If you perceive yourself to be personally discriminated against will you take actions aimed at enhancing the status of the group? Traditional psychological 
theories of collective action, such as relative deprivation theory (e.g., Crosby, 1976; Runciman, 1966; Walker \& Pettigrew, 1984) would suggest not.

Relative deprivation theory offers one of the most detailed discussions on the relationship between perceptions of discrimination and collective action. This theory refers to personal or "egoistic deprivation" and defines it in terms of perceiving oneself to be deprived in relation to others. Perceived personal deprivation has been considered to be irrelevant to collective action-taking because actions to enhance a group's status are presumably an unlikely response to what is perceived to be an individual situation of deprivation. Instead, it has been suggested that an individual perceiving personal discrimination might take individual actions aimed at enhancing their own status. Consistent with this hypothesis, perceptions of personal deprivation have been found to be related to actions that enhance one's individual status (Hafer \& Olson, 1993; Kawakami \& Dion, 1993), but unrelated to participation in collective actions (Barnes \& Kaase, 1979; Birt \& Dion, 1987; Bowen, Bowen, Gawiser \& Masotti, 1968; Geschwender \& Geschwender, 1973; Muller, 1973; Guimond \& Dubé-Simard, 1983; Walker \& Mann, 1987; Walker \& Pettigrew, 1984).

The lack of an empirical association between personal deprivation and collective action however, may be due to the way personal deprivation has been traditionally defined. Personal deprivation has been most commonly defined as occuring in relation to other members of the ingroup; women are asked if they perceive deprivation in relation to other women (Appelgryn \& Bornman, 1996; Birt \& Dion, 1987; Crosby, 1976; Geschwender \& Geschwender, 1973; Hafer \& Olson, 1993; Vanneman \& Pettigrew, 1972; Walker \& Mann, 1987). In contrast, when perceptions of perceiving personal discrimination are defined in relation to the outgroup, perceived personal discrimination may indeed become important in understanding collective action. This would be consistent with the Five Stage model of intergroup relations (Taylor \& McKirnan, 1984), which suggests that group members who recognize they are personally deprived in relation to the advantaged group 
play an important role in consciousness raising and motivating collective action. Empirically, it has been found that women were more likely to take collective action when they perceived both personal (e.g., "I am discriminated against in relation to men") and group discrimination (e.g., "Women are discriminated against in relation to men") than when they perceived group discrimination alone (Foster \& Matheson, 1995). Thus, perceiving personal discrimination in relation to the outgroup appears to play a role in understanding when minority group members will take collective action.

This finding is also consistent with alternative theories of intergroup relations, namely group consciousness theories (Bartky, 1977; Bowles \& Duelli Klein, 1983; Dreifus, 1973; Kimmel, 1989; Lerner, 1986; Stanley \& Wise, 1983). These theories tend to be based the experiences of activists and have been more recently developed in the context of new social movement theories (Cohen, 1985; Friedman \& McAdam, 1992; Gamson, 1992). In contrast to relative deprivation theory, group consciousness theories suggest that in order for collective action to occur, minority group members must recognize their personal experience with discrimination. These theories suggest that women's recognition that they too have personally experienced gender discrimination, involves an understanding that discrimination against members of their group is occurring, but as well, that they themselves are affected by this discrimination. Discrimination therefore becomes redefined as "their problem and my problem". As such, the group's status is likely personally relevant to their own status and collective action may be a more likely response by individual group members. While it may seem that recognizing the group is discriminated against should obviously necessitate recognizing personal discrimination, especially if the individual identifies with the group, past research suggests that while disadvantaged group members recognize their group is discriminated against, they do not necessarily perceive such discrimination to affect them personally (e.g., Crosby, 1982, 1984; Taylor, Wright, Moghaddam \& Lalonde, 1990). This distinction between the group and the individual also occurs when the individual identifies with their 
group (Crosby Pufall, Snyder, O'Connell \& Whalen, 1989, Porter \& Taylor, 1992). Perceiving personal discrimination then, appears to be a different experience from the perception of group discrimination alone, one that group consciousness theories (e.g., Bartky, 1977) suggest is an integral component in taking collective action.

In addition to the cognitive perception of discrimination, individuals may also experience an affective reaction to perceiving discrimination that plays a role in collective action (Runciman, 1966; Walker \& Pettigrew, 1984). For example, a woman may recognize that she has fewer opportunities, and may feel very discontented with her status. Alternatively, she may be happy to have a job, and therefore feel little discontent with her perceived status. Relative deprivation theorists suggest that it those who are highly discontent with their perceived status who will be more motivated to act than those who are not discontent (Dubé \& Guimond, 1986; Martin, 1986; Tougas \& Veilleux, 1988; Runciman, 1966; Walker \& Pettigrew, 1984).

In contrast, some group consciousness theories suggest that high discontent with personal discrimination may impair behaviors such as collective action (Cross, 1971; Downing \& Rousch, 1985). These theories suggest that women who experience high negative feelings with their disadvantaged status may be distracted from participating in behaviors to enhance their group's status.

Instead, they may be focused on dealing with their emotions and as such, are not focused on the problem at hand, namely discrimination. For example, a woman who experiences pay inequity and is highly discontent with her status may be focused on coping with her distress, rather than on how to resolve the problem. In contrast, a woman who perceives personal discrimination, yet is not highly discontent with her status is theorized to be able to focus on ways to resolve the problem of group discrimination with behaviors that would serve to enhance the status of the group. The notion that negative emotion is distracting is consistent with other literatures. For example, the achievement motivation literature has found negative emotions such as anxiety to impair task performance (Brockner \& Fulton, 1978; Heckhausen, 1991; Sarason, 
1975). Literature on coping with depression suggests that a focus on emotion will maintain depression and impair any positive behaviors to alleviate it (e.g., Nolen-Hoeksema, 1991). Thus, according to Downing and Rousch (1985), high discontent may distract women from participating in collective action while lower levels of discontent with one's personal status may enable women to be more focused on participating in collective action.

Given the different perspectives, there is a need to evaluate the role of discontent in motivating collective action. However, empirical research has tended to focus on the cognitive perceptions of discrimination rather than affective reactions (e.g, Abeles, 1976; Appelgryn \& Nieuwoudt, 1988; Barnes \& Kaase, 1979; Crawford \& Naditch,1970; Crosby et al., 1989; Geschwender \& Geschwender, 1972; Vanneman \& Pettigrew, 1972; Van Dyk \& Nieuwoudt, 1990; Walker \& Mann, 1987). When affect has been considered, it is usually considered to be another outcome variable in response to cognitive perceptions of discrimination rather than a predictor of action (Bernstein \& Crosby, 1980; Folger, 1986; Folger, Rosenfield, \& Rheaume, 1983; Olson, 1986), or in relation to attitudes rather than behavior (Appelgryn \& Bornman, 1996; Birt \& Dion, 1987; Guimond \& Dubé-Simard, 1983). As a predictor of attitudes, increased negative affect has been found to be a better predictor of stronger nationalistic (Guimond \& Dubé-Simard, 1983), militaristic attitudes (Birt \& Dion, 1987) and protest orientation (De La Rey \& Raju, 1996) than cognitive perceptions of deprivation. However, the one study did examine collective action (Martin, Brickman \& Murray, 1984) found that feelings of deprivation (affect) were unrelated to endorsement of collective actions. This finding may have resulted because the measures of perceived discrimination combined the cognitive and affective items into a single index of perceived personal discrimination. Therefore, the relative roles of cognition and affect in collective action were unclear.

Given the inconclusive research, the present study therefore sought to examine the relative roles of cognition and affect in taking collective action. If relative deprivation theory is supported, then perceiving personal 
discrimination and feeling personal discontent should be unrelated to collective action. If group consciousness theories are supported, perceiving personal discrimination, but feeling little personal discontent should be related to taking greater collective action.

Method

\section{Participants and Procedure}

Female students $(\mathrm{N}=163$; Mean age $=23)$ from Introductory courses at Carleton University in Ottawa, Canada completed a 30-minute questionnaire assessing their subjective cognitive perceptions of personal discrimination, their affective reactions to those perceptions, as well as their participation in collective actions. Once the questionnaires were completed, students were given an oral and written debriefing regarding the purpose of the study.

The present study was interested in examining the role of women's cognitive and affective responses to personal discrimination in collective action, given that they already recognized their group was discriminated against. Therefore, participants were then included in the analysis only if they reported perceiving group discrimination $1(\mathrm{~N}=117)$.

\section{Materials}

\section{Perceptions of personal discrimination (Foster \& Matheson, 1995). Using a} scale that ranged from disagree strongly (1) to agree strongly (7), perceptions of personal discrimination were assessed by having participants indicate the extent to which they disagreed or agreed with seven statements: "I have equal status relative to men of my peer group", "For the same employment, men will be paid more than I", "I have to work harder than men in my peer group to reach my goals", "I personally have not suffered from the effects of sexual discrimination", "Men have more employment opportunities than I", "I have less power than most men", "I am in an inferior social position compared to men". Reverse scored items were recoded such that on all items, high scores reflected high perceived personal discrimination. The mean rating across all seven items was used as the overall personal discrimination score (Cronbach 
alpha $=.85) . \quad$ Affective reactions to discrimination/Personal discontent.

Consistent with past research (e.g., Martin, Brickman \& Murray, 1984), affective reactions were assessed with feelings of content/discontent. On a separate page, the personal discrimination items were again presented. Participants were asked to re-read each item, keeping in mind how they had rated their personal status. They were then asked to rate each item on a scale of 1 (highly discontent) to 7 (highly content) to indicate how they felt about their perceived status: discontent or content. Thus, participants were providing their affective reactions (in discontent) to their perceptions of discrimination. Reverse scored items were recoded such that high scores reflected high discontent. The mean rating across the seven items was used as the overall scale score $($ Cronbach alpha $=.84$.

Collective action(Foster \& Matheson, 1995). Participants indicated with a check mark which of a list of 25 actions they had participated in during the last six months. Collective action was defined as any behavior directed at enhancing the group status (Wright, Taylor \& Moghaddam, 1990). Behaviors included private actions such as "I have gone out of my way to collect information on women's issues," as well as public actions such as "I have participated in protests regarding women's issues", all aimed at enhancing the status of the group. The list of actions was derived from Lalonde and Cameron (1993) but were reworded to maintain context specificity for women. The total number of actions engaged in during the last six months was used as the overall score. Scores could range from 0 to 25 .

\section{Results}

Descriptive Statistics. Descriptive statistics were examined to assess the degree to which participants reported perceiving personal discrimination, feeling discontent about their perceived status, and participating in collective actions. Participants scored significantly higher than the midpoint on personal discrimination, indicating that they perceived personal discrimination $(\underline{\mathrm{M}}=$ $4.9, \underline{\mathrm{SD}}=1.1, \mathrm{t}(117)=9.24, \mathrm{p}<.001, \underline{\eta} \underline{2}=.65)$. Participants scored significantly below the midpoint on personal discontent, indicating they did 
not feel personally discontent, $(\underline{\mathrm{M}}=2.4, \underline{\mathrm{SD}}=1.3, \mathrm{t}(116)=-13.36, \mathrm{p}<.001, \underline{\mathrm{n}}$ $\underline{2}=.77$ ). In addition, participants reported feeling a lower intensity of discontent relative to the magnitude of discrimination they perceived, $\underline{t}(116)=$ $13.67, \underline{\mathrm{p}}<.0001, \underline{\mathrm{n}} \underline{2}=.62$.

Consistent with past research (e.g., Wright, Taylor \& Moghaddam, 1990), participants took relatively few collective actions $(\underline{M}=7.32, \mathrm{SD}=4.4$, Range $=22$ ). Among the most frequently endorsed actions were private actions such as "I have gone out of my way to collect information on women's issues" (73.5\%), "I make a conscious attempt to use non-sexists language (69.2\%).

Private actions that required slightly greater risk or publicity were also highly endorsed, for instance, "I have discussed women's issues with family or friends, stressing the need to enhance women's position in society" (76. 1\%), "If, in a group of strangers (i.e., people who I haven't know for long, or well), a sexist comment is made, I will make a point of arguing against it" (59\%).

The most public actions showed less endorsement: "I am a member of an organization that deals with women's issues (17.9\%), "I have participated in protests regarding women's issues" (17.1\%).

\section{$\underline{\text { Hierarchical regression analysis }}$}

In order to examine the relative associations between personal discrimination, discontent and collective action, a hierarchical regression analysis was conducted. Collective action was regressed onto personal discrimination and discontent on the first step, and the interaction between personal discrimination and discontent (the product term) on the second step. In order to ensure that the interaction effect would not be a function of differences in variability, the main effects were standardized, and the product term was calculated by multiplying the standardized personal discrimination and discontent scores.

The main effects explained $19.8 \%$ of the variability in collective action, $\underline{F}$ $(2,115)=14.19, \mathrm{p}<.001$. Standardized beta weights indicated that personal discrimination, $\beta=.26, \underline{p}<.01$ as well as personal discontent, $\beta=-.28, \underline{p}<.01$ 
uniquely explained variability in collective action, such that the more women perceived personal discrimination and the less they felt personal discontent, the more they participated in collective action.

The main effects were qualified by a significant interaction effect which predicted an additional $5.8 \%$ of the variability in collective action, $\underline{\mathrm{F}}(1,115)=$ $12.23, \mathrm{p}<.001$. Examination of the final step beta weights (see Table 1) indicated that the main effect for perceived personal discrimination was no longer significant, suggesting that the variability explained by personal discrimination became subsumed under the variability explained by the interaction $(\beta=.38, \underline{p}<.01)$.

To examine the nature of the interaction, median splits were performed on both the raw personal discrimination and discontent simple main effects were analyzed (see Figure 1). The source of the interaction appeared to be from the differential relationship between personal discontent and low, high personal discrimination. Specifically, women reporting high personal discrimination participated in more collective actions when they felt low personal discontent ( $\underline{\mathrm{M}}=8.39)$ than when they felt high personal discontent $(\underline{\mathrm{M}}=4.71, \underline{\mathrm{t}}(113)=$ $-3.23, \mathrm{p}<.01$ ). However, women reporting low personal discrimination did not differ in their participation in collective action as a function of their low ( $\underline{\mathrm{M}}=7.33)$ or high personal discontent $(\underline{\mathrm{M}}=5.79, \mathrm{t}(113)=-.992$, ns.

\section{Discussion}

The present study examined how perceiving personal discrimination and feeling personal discontent would be related to taking collective actions to enhance group status. It was hypothesized that if relative deprivation theory were supported, results would show a lack of association of perceiving personal discrimination and discontent with taking collective action. If group consciousness theories were supported, results would show that perceiving personal discrimination would be related to greater collective action, and personal discontent would be related to less collective action. Consistent with group consciousness theories (e.g., Bartky, 1977; Dreifus, 1973), these 
relationships were supported.

However, these main effects were qualified by an significant interaction between perceiving personal discrimination and feeling personal discontent on collective action. In particular, among women who perceived little personal discrimination, feelings of personal discontent were not differentially related to women's participation in collective action. This is not surprising in that it might be expected that despite perceiving group discrimination, when people do not perceive the problem to be personally relevant (personal discrimination), the strength of their feelings of personal discontent will not likely make a difference in whether they take action.

In contrast, personal discontent was related to participation in collective action among women who perceived high personal discrimination.

Specifically, those who felt low personal discontent took more collective actions than those who felt high personal discontent. Thus, perceiving high personal discrimination and feeling highly discontent regarding one's status appears to play an inhibitory role for taking collective action. This interpretation would be consistent with Downing and Rousch (1985) who suggest that negative emotion distracts women from the task at hand, namely taking collective action.

However, the presence of negative emotions is not necessarily equivalent to a focus on negative emotions. Women may indeed be discontent, but not necessarily be focused on their discontent. Thus, distraction may not explain why collective action decreased for women who perceived personal discrimination and felt personal discontent. It may be that discontent appeared inhibitory because it may encompass emotions that serve to inhibit behaviors to resolve a negative situation, namely anxiety and helplessness. Consistent with learned helplessness theories (e.g., Abramson, Seligman \& Teasdale, 1978), it may be that if discontent involves feelings of anxiety and helplessness, that women who feel personal discontent regarding their perceived personal discrimination, may feel overwhelmed, unable to effect change, and therefore be less likely to participate in collective action. The 
notion that discontent encompasses some level of anxiety and helplessness is consistent with other operational definitions of discontent. For example, when exploring the affective component of relative deprivation, researchers have operationally defined it as participants' ratings of their feelings of dissatisfaction and resentment (discontent), combined with feelings of anxiety, helplessness (De La Rey \& Raju, 1996) and depression (Appelgryn \& Bornman, 1996). If discontent does involve more intense negative emotions such as anxiety and helplessness, then it may indeed serve to inhibit participation in collective action.

The notion that negative emotional reactions to perceived personal discrimination involve anxiety is also consistent with Crosby's (1984) denial hypothesis. Crosby (1984) suggests that the notion of personal disadvantage is so anxiety provoking that minority group members prefer deny that it occurs. For example, in the present study, while women on average perceived personal discrimination, they did not feel discontent about it. Thus it appeared as if women were expressing the opinion that "I'm discriminated against, but I'm not upset about it". Consistent with Crosby (1984), this may suggest that women are "denying" their negative emotional reactions to their perceived personal discrimination because of the associated anxiety.

Indeed, the specific meaning of discontent as it was assessed in the present study is ambiguous, and as such it cannot be assumed that discontent involved feelings of anxiety. Given the lack of empirical research on the relationship between discontent and collective action, the purpose of the present study was to examine the role of a generalized sense of discontent. To do this, the definition of discontent was left open to women's subjective interpretations, rather than limiting their reporting of their negative emotional reactions to a particular feeling. As the present study showed, women's feelings of discontent, however women were defining it, appeared to be inhibitory. Thus, the next step in the research must be to clarify how women are defining their discontent in order to better understand its role in taking collective action.

While the data was consistent with the hypothesis that increased discontent 
may inhibit collective action, the correlational nature of the data cannot preclude the possibility of a recursive relationship. It is also possible that instead of personal discontent inhibiting collective action, collective action may inhibit personal discontent. Participation in action may help women to feel in control of their disadvantaged status in that they are acting to effect change. As such, their discontent regarding their status may decrease. Experimental studies will therefore be necessary to clarify the direction of relationships between personal discontent and collective action.

In summary, the present study found that women who perceived high personal discrimination participated in greater collective action when they felt low discontent than when they were highly discontent. In addition to supporting the various psychological theories that suggest negative emotion is inhibitory (Downing \& Rousch, 1985; Nolen-Hoeksema, 1991; Sarason, 1975), this finding also appears to reflect North American ideology. Indeed, North America's "rugged individualism" ideology trains individuals to believe that they can conquer any problem if they remain "tough" and ignore emotions that make us "weak". In other words, we restrict our emotions we will be able to resolve our problems, but if we let ourselves "feel too much", we will unable to help ourselves.

However, suggesting to minority group members that they lower their personal discontent may not be an appropriate solution for political apathy. First, to suggest that minority group members "get over" their discontent in order to enhance collective action may serve to delegitimize their feelings regarding discrimination. Indeed, given the pervasiveness of discrimination, negative emotional reactions may not be something that victims of discrimination can simply reduce. It may be however, that if negative emotions are defined differently, they may become motivational. For example, the present study only examined general perceptions and reactions to discrimination (e.g., I have less power than most men). If women were responding to a general sense of discrimination, they may be defining discrimination on a more pervasive, or global level. Consistent with learned 
helplessness theories (Abramson, Seligman \& Teasdale, 1978), global attributions are associated with feelings that individuals will be ineffective or helpless to alter their situation. Once the individual feels helpless to alter a situation, they will exhibit passivity, rather than acting to resolve the situation. As such, negative emotions regarding global discrimination may indeed be associated with reduced motivation to participate in collective action. In contrast, if discrimination were measured in relation to a specific situation (e.g., harassment at work), having to take action to resolve this one specific situation may be less overwhelming. Indeed, the thought of being able to change one situation is less overwhelming than having to change many situations. As such, negative emotions regarding a specific instance of discrimination may be more motivational. Indeed, while as the present study suggests, general feelings of personal discontent may inhibit collective action, future research may discover possible ways in which personal discontent may ultimately become motivational.

\section{References}

Abeles, R. P. (1976). Relative deprivation, rising expectations and black militancy. Journal of Social Issues $, \underline{32}, 119-137$.

Abramson, L. Y., Seligman, M. E. P., \& Teasdale, J. (1978). Learned helplessness in humans: Critique and reformulation. Journal of Abnormal Psychology, $, 87,49-74$.

Appelgryn, A. E. M, \& Bornman, E. (1996). Relative deprivation in contemporary South Africa. The Journal of Social Psychology, 136 (3), 381397.

Appelgryn, A. E. M, \& Nieuwoudt, J. M. (1988). Relative deprivation and the ethnic attitudes of Blacks and Afrikaans-speaking Whites in South Africa. The Journal of Social Psychology, 128 (3), 311-323.

Barnes, S. H. \& Kaase, M. (1979). Political action: Mass participation in five western democracies. Beverly Hills, CA: Sage. 
Bartky, S. L. (1977) Toward a phenomenology of feminist consciousness. In M. Vetterling-Braggin, F. Elliston, \& J. English (Eds.), Feminism and philosophy (pp. 22-37). Totawa, NJ: Littlefield.

Bernstein, M. \& Crosby, F. (1980). An empirical examination of relative deprivation theory. Journal of Experimental Social Psychology, 16, 442-456.

Birt, C. M. \& Dion, K. L. (1987). Relative deprivation theory and responses to discrimination in a gay male and lesbian sample. British Journal of Social Psychology,_26, 139-145.

Bowen, D., Bowen, E. Gawiser, S. \& Masotti, L. (1968). Deprivation, mobility, and orientation toward protest of the urban poor. In L. Masotti \& D. Bowen (Eds.), Riots and rebellion: Civil violence in the urban community. Beverly Hills, CA: Sage.

Bowles, G. \& Duelli Klein, R. (1983). Theories of women's studies . London: Routledge.

Brockner, J. \& Hulton, A. J. B. (1978). How to reverse the vicious cycle of low self-esteem: The importance of attentional focus. Journal of Experimental Psychology,_,14, 564-578.

Cohen, J. L. (1985). Strategy or identity: New theoretical paradigms and contemporary social movements. $\underline{\text { Social Research, }}$ 52, 663-716.

Crawford, T. J. \& Naditch, M. (1970). Relative deprivation, powerlessness, and militancy: The psychology of protest. Psychiatry, $\underline{33}$, 208-223.

Crosby, F. J. (1976). A model of egoistical relative deprivation. $\underline{\text { Psychological Review, }}$ 83 , 85-113.

Crosby, F. J. (1982). Relative deprivation and working women . New York: Oxford University Press.

Crosby, F. J. (1984). The denial of personal discrimination. American Behavioral Scientist, 27, 371-386.

Crosby, F. J., Pufall, A., Snyder, R. C., O'Connell, M. \& Whalen, P. (1989) 
The denial of personal disadvantage among you, me, and all other ostriches. In M. Crawford, \& M. Gentry (Eds.), Gender and thought: Psychological perspectives (pp. 79-99). New York: Springer-Verlag.

Cross, W. E. (1971). The Negro-to-Black conversion experience. Black World, 20, 13-27.

De La Rey, C., \& Raju, P. (1996). Group relative deprivation: Cognitive versus affective components and protest orientation among Indian South Africans. The Journal of Social Psychology, 136 (5), 579-588.

Driefus, C. (1973). Women's fate: Rap from a feminist consciousnessraising_group. New York: Bantam.

Downing, N. E., \& Rousch, K. L. (1985). From passive acceptance to active commitment: A model of feminist identity development for women. The Counselling Psychologist, $\underline{13}$, 695-709.

Dubé, L., \& Guimond, S. (1986). Relative deprivation and social protest: The personal-group issue. In J. M. Olson, C. P. Herman \& M. P. Zanna (Eds.), Relative deprivation and social comparison: The Ontario symposium ( $\mathrm{Vol} 4$, pp. 201-216). Hillsdale, NJ: Lawrence Erlbaum Associates.

Folger, R., (1986). A referent cognitions theory of relative deprivation. In J. M. Olson, C. P. Herman \& M. P. Zanna (Eds.), Relative deprivation and social comparison: The Ontario symposium (Vol 4, pp. 33-55). Hillsdale, NJ: Lawrence Erlbaum Associates.

Folger, R., Rosenfield, D. \& Rheaume, K. (1983). Role playing effects of likelihood and referent outcomes on relative deprivation. Representative Research in Social Psychology,_, 13, 2-10.

Foster, M. D., \& Matheson, K. (1995). Double relative deprivation: Combining the personal and political. Personality and Social Psychology. Bulletin, 21, 1167-1177.

Friedman, D. \& McAdam, D. (1992). Networks, choices and the life of a 
social movement. In A. D. Morris \& C. McClurg Mueller (Eds.), Frontiers in Social Movement Theory (pp.156-173). New Haven: Yale University Press.

Gamson, W. A. (1992). The social psychology of collective action. In A. D. Morris \& C. McClurg Mueller (Eds.), Frontiers in Social Movement Theory (pp. 53-76). New Haven: Yale University Press.

Geschwender, B. N. \& Geschwender, J. A. (1973). Relative deprivation and participation in the civil rights movement. Social Science Quarterly, $\underline{54}$, 268-273.

Guimond, S., \& Dubé-Simard, L. (1983). Relative deprivation theory and the Quebec nationalist movement: The cognition-emotion distinction and the personal-group deprivation issue. Journal of Personality and Social Psychology,

Hafer, C. L., \& Olson, J. M. (1993). Beliefs in a just world, discontent and assertive actions by working women. Personality and Social Psychology. Bulletin, 19, 30-38.

Heckhausen, H. (1991). Motivation and action. New York: SpringerVerlag.

Kawakami, K., \& Dion, K. L. (1993). The impact of salient self-identities on relative deprivation and action intentions. European Journal of Social Psychology, 23 , 525-540.

Kimmel, E. B. (1989). The experience of feminism. Psychology of Women Quarterly,_13, 168-186.

Lalonde, R. N., \& Cameron, J. E. (1993). Behavioral responses to discrimination: The focus on action. In M. P. Zanna \& J. M. Olson (Eds.), The psychology of prejudice: The Ontario Symposium (Vol. 7, pp. 257-288). Hillsdale, NJ: Erlbaum.

Lerner, G. (1986). The creation of patriarchy. New York: Oxford 
University Press.

Martin, J. (1986). The tolerance of injustice. In J. M. Olson, C. P. Herman \& M. P. Zanna (Eds.), Relative deprivation and social comparison: The Ontario symposium (Vol 4, pp. 217-242). Hillsdale, NJ: Lawrence Erlbaum Associates.

Martin, J., Brickman, P., \& Murray, A. (1984). Moral outrage and pragmatism: Explanations for collective action. Journal of Experimental Social Psychology, 20, 484-496.

Muller, E. N. (1972). A test of the partial theory of potential for political violence. American Sociological Review, $\underline{38}$, 721-732.

Nolen-Hoeksema, S. (1991). Responses to depression and their effects on the duration of depressive episodes. Journal of Abnormal Psychology, $\underline{100}$, 469-482.

Olson, J. M. (1986). Resentment about deprivation: Entitlement and hopefulness as mediators of the effects of qualifications. In J. M. Olson, C. P. Herman \& M. P. Zanna (Eds.), Relative deprivation and social comparison: The Ontario symposium (Vol 4, pp. 57-77). Hillsdale, NJ: Lawrence Erlbaum Associates.

Porter, L. E., \& Taylor, D. M. (1992, June). The personal/group discrimination discrepancy: The role of social identity. Paper presented at the annual convention of the Canadian Psychological Association, Quebec, Canada.

Runciman, W. G. (1966). Relative deprivation and social justice: A study of attitudes to social inequality in twentieth century England . Berkeley, CA: University of California Press.

Sarason, I. G. (1975). Anxiety and self-preoccupation. In I. G. Sarason \& C. D. Spielberger (Eds.). Stress and anxiety Vol.2. New York: John Wiley and Sons. 
Stanley, L. \& Wise, S. (1983). Breaking out: feminist consciousness and feminist research. London: Routledge \& Kegan Paul.

Taylor, D. M., \& McKirnan, D. J. (1984). A five-stage model of intergroup relations. British Journal of Social Psychology, 23, 291-300.

Taylor, D. M., Wright, S. C., Moghaddam, F. M. \& Lalonde, R. N. (1990). The personal/group discrimination discrepancy: Perceiving my group, but not myself, to be a target for discrimination. Personality and Social Psychology Bulletin, 16, 254-263.

Tougas, F., \& Veilleux, F. (1988). The influence of identification, collective relative deprivation and procedure of implementation on women's response to affirmative action: A causal modeling approach. Canadian Journal of Behavioral Science, $\underline{20}, 15-28$.

Van Dyk, A. C., \& Nieuwoudt, J. M. (1990). The relationship between relative deprivation and the attitudes of rural Afrikaans-speaking women toward Blacks. The Journal of Psychology, 124 (5), 513-521.

Vanneman, R. D., \& Pettigrew, T. F. (1972). Race and relative deprivation in the urban United States. Race, 13, 461-486.

Walker, I., \& Mann, L. (1987). Unemployment, relative deprivation and social protest. Personality and Social Psychology_Bulletin, $\underline{13}$, 275-283.

Walker, I., \& Pettigrew, T. F. (1984). Relative deprivation theory: An overview and conceptual critique. British Journal of Social Psychology, $\underline{23}$, 301-310.

Wright, S. C., Taylor, D. M., \& Moghaddam, F. M. (1990). Responding to membership in a disadvantaged group: From acceptance to collective protest. Journal of Personality and Social Psychology, , 58, 994-1003.

\section{Author Note}

Correspondence should be addressed to Mindi D. Foster, at the Department of Psychology, 
University of North Dakota. P.O. Box 8380, Grand Forks, North Dakota.

58202-8380. Phone: (701) 777-4496. Email: foster@badlands.nodak.edu.

\section{Footnotes}

1 Group discrimination was measured using the group-level counterparts of the personal discrimination items: "Women have equal status with men"; "For the same employment, men will be paid more than women"; "Women have to work harder than men to reach their goals"; Women do not suffer from the effects of sexual discrimination"; Men have more employment opportunities than women"; "Women have less power than men"; "Women are in an inferior social position compared to men". Participants rated these items using a scale ranging from disagree strongly (1) to agree strongly (7). Reverse scored items were recoded such that on all items, high scores reflected high perceived personal discrimination. The mean rating across all seven items was used as the overall group discrimination score (Cronbach alpha $=.89$ ). Participants were selected if they scored above the midpoint.

Table 1

$\underline{\text { Regression of collective action onto main effects, interaction }}$ $\underline{\mathrm{r}} \quad \underline{\mathrm{R}} \underline{2} \underline{\text { unique }} \mathrm{R} \underline{2} \underline{\text { total }}$

$\begin{array}{lllll}\text { Personal discrimination } & .36^{* *} & -.04 & \\ \text { Personal discontent } & -.38^{* *} & -.52^{* *} & .198^{* *} \\ \text { Interaction } \quad .20^{* *} & .38^{* *} & .058^{*} \quad .256^{* *}\end{array}$

Note: Beta refers to the final step beta weights

$$
* * \mathrm{p}<.01
$$

Figure Caption

Figure 1. The interaction between personal discrimination and personal discontent on collective action. 